\title{
Benin responds to covid-19: sanitary cordon without generalized containment or lockdown?
}

\author{
Issideen Ayinla Osseni ${ }^{1,2}$ (B)
}

\begin{abstract}
Since the novel coronavirus disease 2019 (COVID-19) has been identified in Wuhan, China, in the last week of December, the virus has spread across nations and continents affecting over 3 million people and putting the whole world to a halt. Nations across the globe went on lockdown in an attempt to contain the spread of the virus and curb its propagation curve. Affected African countries did the same except for Benin, which opted for a sanitary cordon around the affected regions with free movement of people. The biggest challenge is the effectiveness of this measure.
\end{abstract}

Keywords: COVID-19, Low-income country, Containment, Lockdown, Sanitary cordon, Benin

To the Editor,

In a matter of 4 months, COVID-19 has spread across nations and is currently affecting all continents except for Antarctica. On 11 March 2020, it was declared a pandemic by the World Health Organization [1]. The African Continent has the second least number of cases and deaths from COVID-19 after Oceania [2]. In an attempt to flatten the curve of the virus propagation, nations across the globe opted for generalized containment or lockdown measures causing malls, bars, restaurants, shops, etc. to close [3, 4] allowing African countries to follow suit. Though enforcing this mitigation measure will negatively impact the economy, it will subsequently cause a decline in the annual GDP [5]. However, the economic repercussions will differ depending on the living conditions and access to essential services of a country's population. Low-income countries like Benin will face tremendous economic hardship because there is a high reliance on informal activities [6]. Since a large portion of Benin's population depends on a daily or weekly wage, the economic drawback of such mitigation

\footnotetext{
Correspondence: osseni.isdeen@yahoo.com

'Department of Clinical Medicine, International School, Jinan University,

510632 Guangzhou, People's Republic of China
}

2Department of Medicine, UAC Health Sciences Faculty, Cotonou, Benin measures undoubtedly outweighs the benefit of enforcing a generalized containment or lockdown $[7,8]$.

In an attempt to contain COVID-19, in early February, Benin government prevention efforts were to screen all flight passengers coming into the country. The Ministry of Health installed a temperature scanner, handwashing apparatus, and an isolation room in the country's international airport as air traffic is a major facilitator in COVID-19 distribution [7, 8]. As COVID-19 first report makes the news in Benin's capital, Porto-Novo on 16 March 2020, the government introduced stricter measures to prevent the rise in cases (Table 1).

In his address to the country on national television on 29 March 2020, Benin's President, Patrice Talon explained how alarming the situation was, he called on the public responsibility and tried to explain the different mitigation measures his government is putting in place [10]. He recognized how the majority of the population rely on informal labor and clarified to why it was virtually impossible to take harsher containment measures and locking down the country. Furthermore, he explained how a sanitary cordon is more appropriate to the country's reality and which areas are to be included (Fig. 1) since failure to quickly contain the virus would result in its significant spread throughout the rest of the

(c) The Author(s). 2020 Open Access This article is licensed under a Creative Commons Attribution 4.0 International License, which permits use, sharing, adaptation, distribution and reproduction in any medium or format, as long as you give appropriate credit to the original author(s) and the source, provide a link to the Creative Commons licence, and indicate if changes were made. The images or other third party material in this article are included in the article's Creative Commons licence, unless indicated otherwise in a credit line to the material. If material is not included in the article's Creative Commons licence and your intended use is not permitted by statutory regulation or exceeds the permitted use, you will need to obtain permission directly from the copyright holder. To view a copy of this licence, visit http://creativecommons.org/licenses/by/4.0/. 


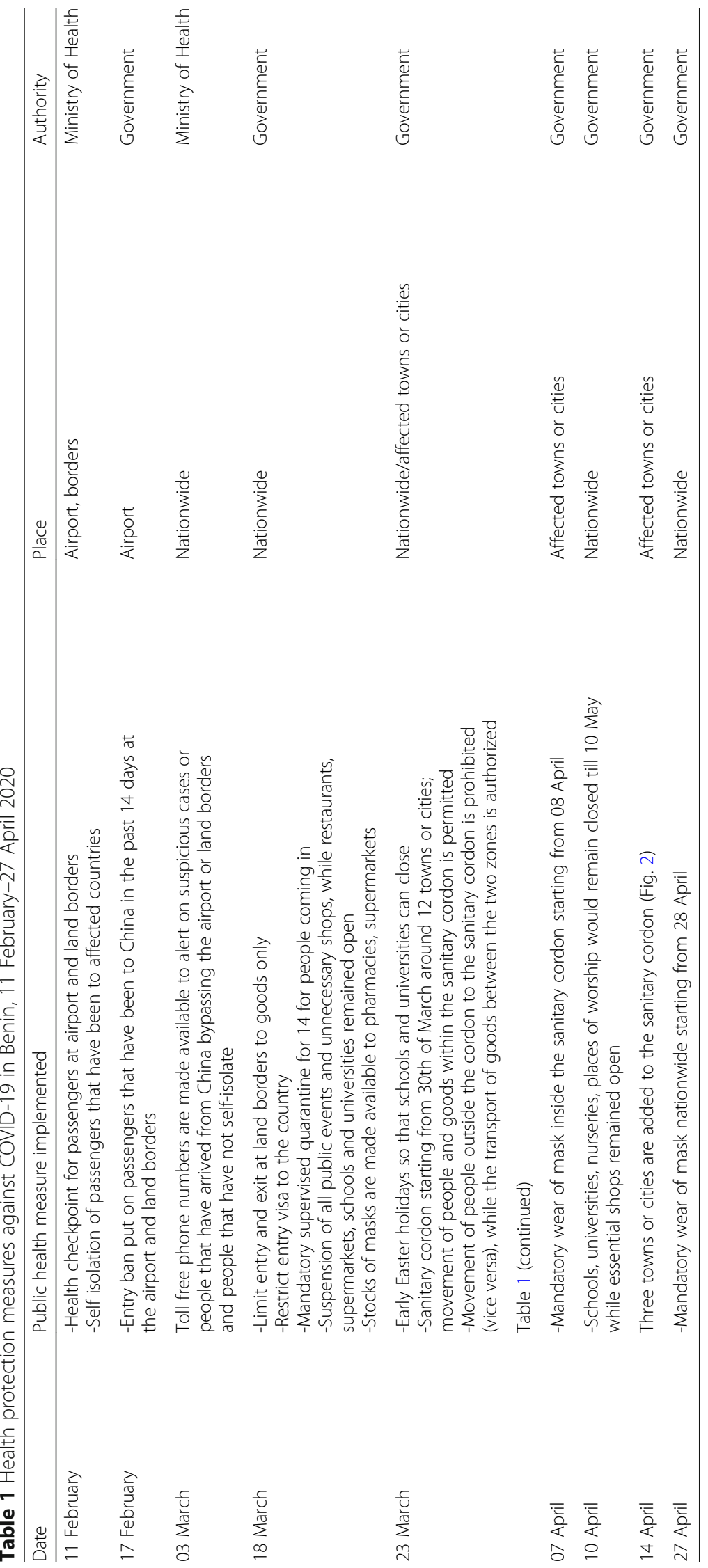



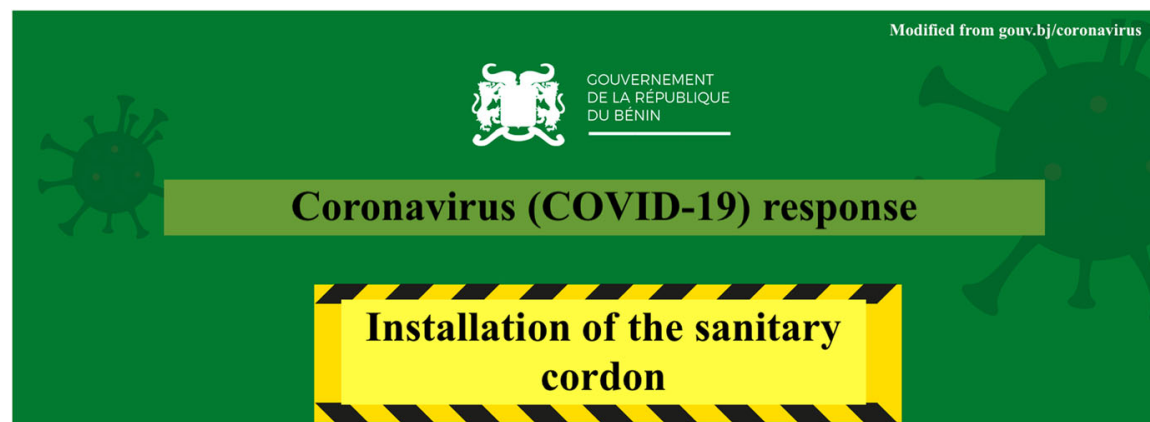

\section{2}

From Monday midnight March, 30th 2020 to Sunday midnight April, 12th 2020

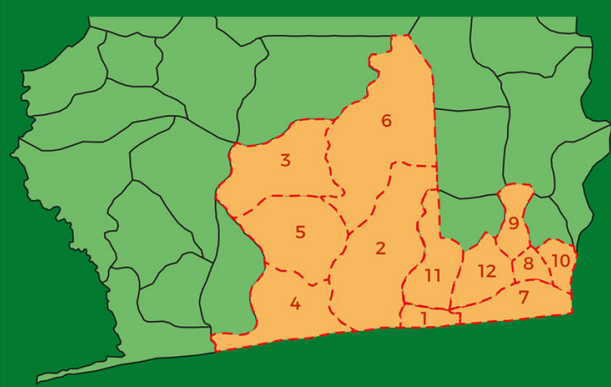

Towns or Cities concerned

(1) Cotonou

(2) Abomey-Calavi

(3) Allada

(4) Ouidah

5- Tori-Bossito

6- Zè

(7) Sèmè-Podji

8 - Porto-Novo

9- Akpro-Missérété

(10) Adjarra

11) Sô-Ava

12. Aguégués

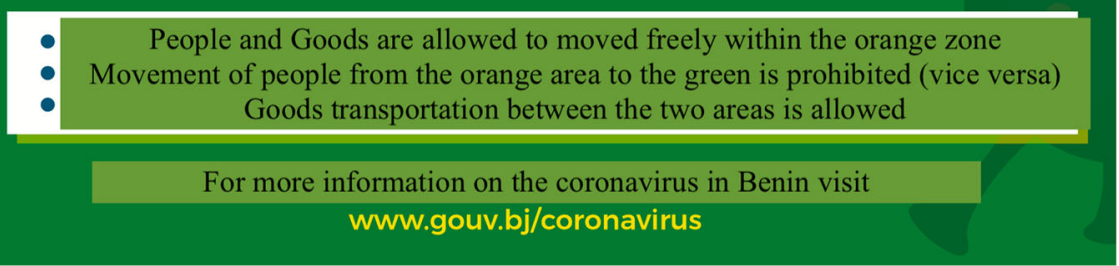

Fig. 1 Sanitary cordon as of March 30 around 12 towns or cities. Data derived from "Gouvernement de la Republique du Benin" COVID-19 webpage (https://www.gouv.bj/actualites/categorie/coronavirus\%2D\%2Dcovid-19-/) [9]

country [11]. Besides, he insisted that people inside the sanitary cordon have freedom of movement while respecting handwashing and hygiene measures.

Mitigation measures at first had been promoting handwashing and hygiene by installing handwashing equipment on the streets, along with social distancing. Individuals that were in Chinese territories during the past 14 days were not allowed in Benin and those coming from other affected countries were asked to selfisolate. Afterward, the government added on stricter measures such as the closure of churches, mosques, clubs, bars while restaurants and supermarkets were left open [9] Fig. 2.

Although the country is already burdened by infectious diseases such as Lassa fever, malaria, and tuberculosis, adding COVID-19 pandemic, these mitigation measures seem inappropriate and insufficient for a lowincome country. Additionally, the country faces several health challenges such as limited access to beds, ventilators, intensive care units, laboratories, and is profoundly short on specially trained clinicians [12, 13]. Hitherto,
Benin's government was able to contain the virus to three community cases while the rest of the cases were diagnosed and restrained during the mandatory 14 days supervised quarantine. As of 28 April 2020, the country counts 64 COVID-19 cases (Fig. 3), 30 cases under treatment, 33 cured cases, and one death [9]. An element of luck was that, after the Lassa fever outbreak in January 2016, with the support of the World Health Organization (WHO), there were significant improvements in the surveillance, emergency response, and prevention of infectious diseases. The capacities of Benin with its neighboring countries were boosted [14]. Today, the government makes use of social media to pass information to the population in different languages and dialects to combat misinformation and safeguard the national public health and safety

\section{Conclusion}

In the span of a couple of months, COVID-19 has severely challenged the world. To prevent the virus spread, nations across the world went on lockdown fully knowing the economic drawback of such measures. Conscientious of its 


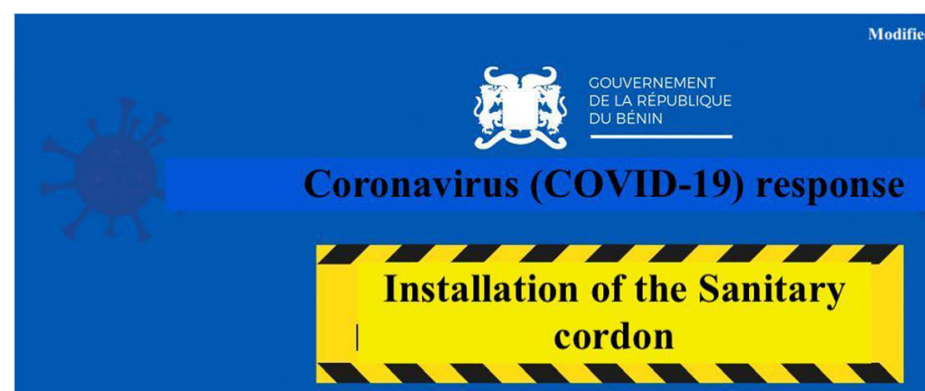

From Monday midnight March, 30th 2020 to Monday midnight April, 27th 2020

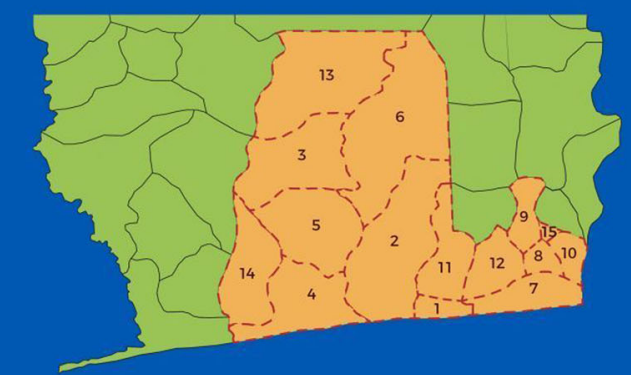

Towns or Cities concerned

(1) Cotonou
2- Abomey-Calavi
3- Allada
(4) Ouidah
5- Tori-Bossito
6 - Zè
(7) Sèmè-Podji
8- Porto-Novo

9. Akpro-Missérété

(10. Adjarra

(17) Sô-Ava

12. Aguégués

13- Toffo

14. Kpomassè

15 Atchoukpa

(Avrankou)

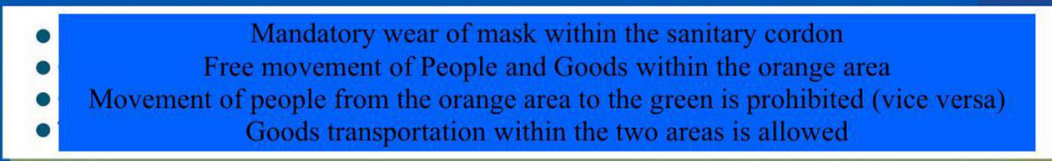

For more infromation on the coronavirus in Benin visit www.gouv.bj/coronavirus

Fig. 2 Sanitary Cordon as of April, 14 around 15 towns or cities. Data derived from "Gouvernement de la Republique du Benin" COVID-19 webpage (https://www.gouv.bj/actualites/categorie/coronavirus\%2D\%2Dcovid-19-/) [9]

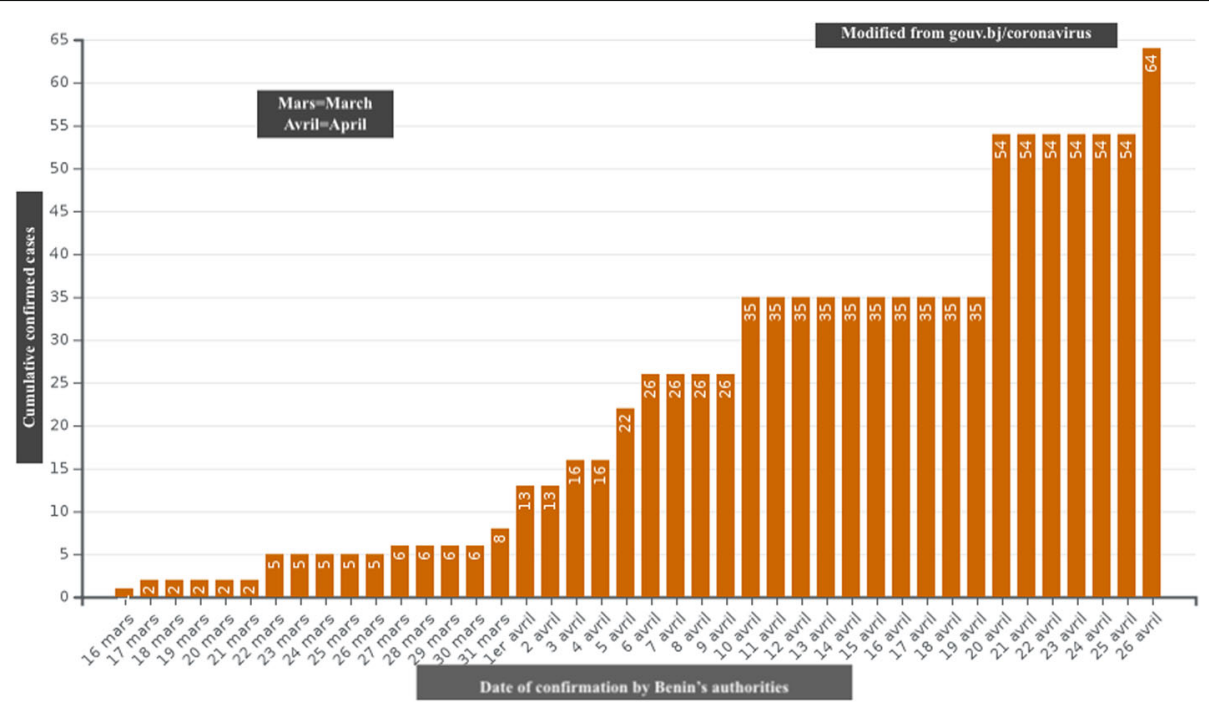

Fig. 3 COVID-19 cases detection timeline. Data derived from "Gouvernement de la Republique du Benin" COVID-19 webpage (https://www.gouv.bj/actualites/categorie/coronavirus\%2D\%2Dcovid-19-/) [9] 
fragile economy, Benin's government settled on creating a sanitary cordon around the affected areas with free movement of the population within it while appealing for the public's responsibility, promoting handwashing and hygiene along with social distancing. Although the sanitary cordon measure is effective in preserving the economic costs on the household level and containing the spread of the virus, it is however expected that people will find ways to intrude in and out of the sanitary cordon which will eventually lead to COVID-19 spreading to other towns or cities.

\section{Abbreviations}

COVID-19: Coronavirus disease 2019; WHO: World Health Organization

\section{Acknowledgements}

Not applicable

\section{Author's contributions}

OIA alone contributed to this paper. The author read and approved the final manuscript.

\section{Funding}

No funding was used to write this paper.

\section{Availability of data and materials}

All data used are publicly available, and sources are cited throughout.

\section{Ethics approval and consent to participate}

Not applicable

\section{Consent for publication}

Not applicable

\section{Competing interests}

There are no conflicts of interest.

Received: 5 May 2020 Accepted: 4 June 2020

Published online: 15 June 2020

\section{References}

1. Domenico Cucinotta, M. V. (2020). WHO declares COVID-19 a Pandemic. (E. o. Biomedica, Ed.) Acta Biomedica, 91 (Vol. 91 No.1 (2020)), 157-160.

2. Control, E. C. (2020, April 26). European Centre for Disease Prevention and Control. (An agency of the European Union) Retrieved april 26, 2020, from https://www.ecdc.europa.eu/en/geographical-distribution-2019-ncov-cases

3. lacobucci G. Covid-19: UK lockdown is "crucial" to saving lives, say doctors and scientists. The British Medical Journal 2020;368:m1204.

4. Gopalkrishna Barkur VG. Sentiment Analysis of Nationwide Lockdown due to COVID 19 Outbreak: Evidence from India. Asian J Psychiatr. 2020;51:102089.

5. Development, O. f. (2020, April 14). Organization for Economic Cooperation and Development. (Organisation for Economic Co-operation and Development) Retrieved April 27, 2020, from https://www.oecd.org/ coronavirus/policy-responses/evaluating-the-initial-impact-of-covid-19containment-measures-on-economic-activity/.

6. Project, T. A. Vulnerability to COVID-19 containment measures. Geneva: ACAPS; 2020.

7. Hien Lau, V. K. (2020a). The association between international and domestic air traffic and the coronavirus (COVID-19) outbreak. Journal of Microbiology, Immunology and Infection.

8. Hien Lau VK. The positive impact of lockdown in Wuhan on containing the COVID-19 outbreak in China. Journal of Travel Medicine. 2020b;27:3.

9. Benin, G. d. (2020, April 16). Gouvernement de la Republique du Benin. (Gouvernement de la Republique du Benin) Retrieved April 26, 2020, from https://www.gouv.bj/actualites/categorie/coronavirus\%2D\%2Dcovid-19-/ page/1/.

10. Talon PP. Réponses du Bénin à la COVID-19_le Président PATRICE TALON en parle; 2020, March 29.
11. Veria Khosrawipour, H. L. (2020). Failure in initial stage containment of global COVID-19 epicenters. Journal of Medical Virology.

12. Edwin Nuwagira CM. Is Sub-Saharan Africa prepared for COVID-19? Tropical Medicine and Health. 2020:48:18.

13. Paintsil, E. (2020). COVID-19 threatens health systems in sub-Saharan Africa: the eye of the crocodile. The Journal of Clinical Investigation.

14. Organization, W. H. (2016, June 13). World Health Organization. (World Health Organization) Retrieved April 27, 2020, from https://www.who.int/csr/ don/13-june-2016-lassa-fever-benin/en/.

\section{Publisher's Note}

Springer Nature remains neutral with regard to jurisdictional claims in published maps and institutional affiliations.
Ready to submit your research? Choose BMC and benefit from:

- fast, convenient online submission

- thorough peer review by experienced researchers in your field

- rapid publication on acceptance

- support for research data, including large and complex data types

- gold Open Access which fosters wider collaboration and increased citations

- maximum visibility for your research: over $100 \mathrm{M}$ website views per year

At BMC, research is always in progress.

Learn more biomedcentral.com/submissions 